\title{
A HAZAI REGIONÁLIS GAZDASÁGTAN ÉS TÁRSADALMI KÖRNYEZETE
}

\author{
Nemes Nagy József
}

A regionális gazdaságtan határtudomány. Elméleti-szemléleti alapjait, fogalmait, eszközeit—módszereit alapvetổen a nevében szereplổ két diszciplínából meríti, a duális jelleg ugyanakkor esélyt teremt a visszahatásra is: a regionális (térbeli) nézôpont megjelenítésére a közgazdaságtanban, a közgazdasági szemlélet, problematika bevitelére a területi tudományokba. (Kár, hogy ezek szükségességérốl, hasznáról leginkább csak a regionalisták vannak meggyổzổve.) A határtudományi karakter következtében a regionális gazdaságtan teljességében nem sorolható be az említett két nagyobb diszciplína egyikébe sem, ahhoz ugyanakkor, hogy saját lábán megállni képes, önálló tudományként mûveljük, mindkét oldalról masszív alapokra van szükség. Vita tárgya lehet, hogy nálunk ezek az alapok mennyire szilárdak, illetve labilitásuk milyen kỏvetkezményekkel jár. Az biztos, hogy a letisztult elméleti bázis, a törvényszerũségek (paradigmák) hiânyát én inkább a regionális tudomány oldalán érzem, a közgazdaságtudományból több ilyen építớkocka emelhetố át. Errốl az oldalról azonban - s ezt felerốsíti a hazai regionális kutatások erốteljes alkalmazás(fốként tervezési)-orientáltsága - a konkrét társadalmi körülmények szélsôséges torzulásai tették alapjaiban kérdésessé a diszciplína ,tudományosságát".

Mirôl van ez utóbbi esetben szó? Arról a rendszerspecifikus alapkérdésról - mely érthetốbben megfogalmazható sarkítva, mint árnyaltan —, hogy a , létezó szocializmus" gazdasága nevezhetõ-e egyáltalán gazdaságnak? A hazai regionális gazdaságtan (s talán a közgazdaságtan más részei is) összes tehetségével, jószándékával, erólködésével együtt az elmúlt évtizedekben abban a csapdában vergődött, hogy - mi mást tehetett volna - alapvetố közgazdasági fogalmakkal operálva próbálta leírni, magyarázni a társadalom gazdaságnak nevezett alrendszerét, miközben ezek a fogalmak (kategóriák) a valóságban nem, vagy csak , szimulálva”, mủvi, torzított formában léteztek és mozgásfolyamataikat alig-alig irányították immanens gazdasági hatótényezók, törvények, hanem sokkal inkább gazdaságon kívüli tényezók, az ideológia, a politika, a hatalmi, szervezeti szempontokat érvényesítô, titkos és szemérmetlen alkufolyamatok, lobbizások. (A gazdaságnak bizonyos szegmensei - ugyancsak sok szempontból torzult formában, nem egyszer jogi, törvényi legalitás keretein kívül - a múltban is felmutattak gazdasági jegyeket. Így mindenekelởtt az ún. második gazdaság, a háztáji és kisegítổ tevékenységek, a magánszektor. Az ezekrốl rendelkezésre álló - igaz kezdetleges és hézagos — vizsgálati eredmények ebból következóen rejthetnek metodikai és prognosztikai elemeket, ötleteket a jövốre tekintve is.)

Az említett mechanizmusnak, alapdetermináltságnak jól megragadható a , területi' tükörképe, vetülete is: a gazdaság (de lényegében az egész társadalom) térbeli szervezôdését, térfolyamatait e mechanizmusokon keresztül , területen kivüli" és ,,területek feletti" erók, szempontok orientálták, irányították. A gazdasági térszerkezet változásai látszólag ugyan , területi" folya- 
matok voltak, de a valóságban a tér (de mondhatnám az egyént, a települést, a térséget is) oldaláról alig befolyásolható, véletlen, területi hatásaiban át nem gondolt következmények (lásd a gyakran emlegetett ágazati szemléletet).

A jövốben mindezért a társadalmi rendszerben bekövetkezố - bizonyára ellentmondásokkal teli - változások hozhatják a regionális gazdaságtant, mint tudományt is olyan helyzetbe, hogy esélye legyen a valóságos magyarázó jellegú összefüggések feltárására olymódon, hogy saját tárgyát, fogalmait, a teret és a gazdaságot elemzi, vizsgálja. (A múlt területi gazdasági folyamatainak megértéséhez, magyarázatához elsôdlegesen a politikai-hatalmi mechanizmus vizsgálatában van a kulcs.)

A változó társadalmi-gazdasági körülmények a regionális gazdaságtan jónéhány alapfogalmában, irányzatában hangsúlyeltolódást, esetenként éles fordulatot kényszerítenek ki. Ilyen fogalmi hangsúlyeltolódás példájaként említhetem azt, hogy a regionális gazdaságtan, a regionális gazdaságpolitika olyan korábbi központi fogalma és problémaköre, mint a gazdaság (elsốsorban az ipar) telepítése helyébe a település, terjedés fogalma kerül.

A gazdaság változó szervezeti, tulajdoni, irányítási jegyei hatására a makroregionális közelítés dominanciája eltũnik (vagy legalábbis tartalmában alapvetôen módosul), s a mikrogazdasági közelítés kerülhet elôtérbe. A makro-mikro közelítés szembeállításakor érdemes azonban egy rövid kitérốt tenni s felhívni a figyelmet egy sajátos paradoxonra. Ha a regionális gazdaságtan, mint tudomány vagy akár a gazdaságpolitika oldaláról tesszük mérlegre a mikrogazdaságtani problémák elốtérbe kerülésének várható trendjét, egyértelmũ az, hogy tudományos érdeklốdésre nem elsôsorban egy-egy gazdálkodó egység (új magángazdaság, kisvállalkozás) tarthat számot, hanem az ezekbốl felépülố új makroszerkezet, a sok kis egység térbeli szervezôdése, viselkedése, mint tömegjelenség (stochasztikus jellegú térfolyamat) tudományos elemzése. Ebból az is következik, hogy a tudomány eredményeire igényt tartó - $\mathrm{s}$ ezért azt finanszírozó - társadalmi szereplố a jövốben is elsốdlegesen az allam (a központi és helyi államigazgatás, önkormányzat) lehet, valamint a kisszervezeteket integráló intézmények (pl. érdekszövetségek), illetve a legnagyobb cégek, bankok (lásd: a világcégek kutatási, tervezési hátterét). Az egyes kisgazda, a vegyesbolt tulajdonosa sehol sem a regionális gazdaságtan eredménytelenségétől szenved, hem abból gazdagszik meg (vagy legalábbis nem tud róla).

Amint a fenti néhány gondolatból kitũnik, alapjaiban új körülmények (,,talajviszonyok") látszanak alakulni tudományunk körül. Ezek befogadására, az új kérdések megválaszolására ma még csak egyes elemeiben alkalmas a hazai regionális gazdaságtan, illetve az azt (és környékét) mûvelốk apró csapata. Magam azonban esélyt látok arra, hogy — erôfeszítésekkel, új közelítésekkel és a tudományág valóságos szellemi piacának megteremtésével, ahol az érték hasznot hoz, a bóvli az eladó nyakán marad - képesek leszünk a jövốben is értelmes és hasznos szellemi erổfeszítésekre, árutermelésre. E folyamat elindításához lökést adhat e szeminárium is, amelynek létrejöttéért a szervezốket köszönet illeti. 